\title{
Correction to: Cost Effectiveness of Cladribine Tablets for the Treatment of Relapsing-Remitting Multiple Sclerosis in The Netherlands
}

\author{
Renée Else Michels ${ }^{1} \cdot$ Maria De Francesco ${ }^{2} \cdot K_{\text {Koshu Mahajan }}^{3} \cdot$ Gerald J. D. Hengstman $^{4} \cdot$ Krijn M. H. Schiffers $^{5}$. \\ Sangeeta Budhia ${ }^{6} \cdot$ Gerard Harty $^{7} \cdot$ Marieke Krol $^{1}$ (D)
}

Published online: 14 January 2020

(c) The Author(s) 2020

\section{Correction to: \\ Applied Health Economics and Health Policy (2019) 17:857-873 \\ https://doi.org/10.1007/s40258-019-00500-8}

The second author's name should be "Maria De Francesco" rather than "Maria de Fransesco".

The corresponding author's email address should be “Marieke.Krol@iqvia.com”rather than “mkrol@iqvia. com".

Open Access This article is licensed under a Creative Commons Attribution-NonCommercial 4.0 International License, which permits any non-commercial use, sharing, adaptation, distribution and reproduction in any medium or format, as long as you give appropriate credit to the original author(s) and the source, provide a link to the Creative Commons licence, and indicate if changes were made. The images or other third party material in this article are included in the article's Creative Commons licence, unless indicated otherwise in a credit line to the material. If material is not included in the article's Creative Commons

The original article can be found online at https://doi.org/10.1007/ s40258-019-00500-8.

Marieke Krol

Marieke.Krol@iqvia.com

1 IQVIA, Real World Evidence Solutions, Herikerbergweg 314, 1101 CT Amsterdam, The Netherlands

2 IQVIA, Real World Insights, Da Vincilaan 7, 1930 Zaventem, Belgium

3 IQVIA, Real World Insights, Gurgaon, India

4 Department of Neurology, Catharina Hospital, Michelangelolaan 2, 5623 EJ Eindhoven, The Netherlands

5 Merck B.V., Tupolevlaan 41-61, 1119 NW Schiphol-Rijk, The Netherlands

6 PAREXEL International, PAREXEL Access Consulting, London, UK

7 EMD Serono, a business of Merck KGaA, Boston, MA, USA licence and your intended use is not permitted by statutory regulation or exceeds the permitted use, you will need to obtain permission directly from the copyright holder. To view a copy of this licence, visit http://creativecommons.org/licenses/by-nc/4.0/. 